\title{
The Veladero hill integrated ecosystem to the touristic sustainability of Acapulco, Mexico
}

\author{
H. Avilez, T. Rivas, Ma. E. Chavarría \& A. Jaimes \\ Unidad Académica de Turismo, \\ Universidad Autónoma de Guerrero, México
}

\begin{abstract}
The focus of the research is to explore one of the socioeconomic environmental phenomena known as the Protected Natural Areas (PNA) and to assess the impact on the host community of Acapulco as well as presenting sustainability evidence or the stage of environmental risk to establish a critical route of viability for its rescue. The location of Veladero hill is a large protected area located in the upper zone or amphitheater of Acapulco bay, Mexico, to the south of Mexico. It consists of an area of 3,159 hectares. With an expropriate decree of 1980 establish for its public use, the national park on the lands that by its location, configuration, topography, exceptional beauty, scientific worth, educative, recreational when needed, assists as an ecosystem to the improvement of the living conditions and welfare of the community, contributing the tourism development; as well as performing the necessary works for its conditioning and organization. Nevertheless, the regulatory framework establishes the conservation to the ecosystems, biodiversity including the ecological processes, natural changes and the eco-systemic services that permit the continuity, evolution of life, progress of human society through a set of policies, protection measures, inclusive management for sustainable use, restoration, involving knowledge processes, culture and management to the whole of society and the government in particular to rural communities, fishing and indigenous in the protected area. Finally, the Veladero hill for its vocation and skills is suitable for the establishment of a national park. However, given the laxity of authority, diverse areas have been occupied for residential purposes, which are a detriment to the preservation of its flora and wildlife, propitiating its erosion and contributing to gradual environmental degradation.
\end{abstract}

Keywords: protected natural areas, ecosystems, evolution of life, protection measures. 


\section{Introduction}

The location of the Veladero hill is a large protected area located in the upper area or amphitheater of the bay of Acapulco, Guerrero, southern Mexico. It has an area of 3,159 hectares. Cartographically, the park is situated in the topographic map at 1:50,000 scale, called Acapulco, Keyed E14-C57, published by the National Institute of Statistics, Geography [1]. Representing humid tropical climate with summer rains and dry in winter. The annual average temperature is $27.8^{\circ} \mathrm{C}$.

The Veladero is a large mountainous area surrounding the bay of Acapulco. Its steep slopes and fanciful moldings, cliffs, peaks, and natural roughness, are the ideal space for marketing a variety of tourist attractions. The extra benefits offered by the abrupt changes of the terrain are accompanied by many hazards as well. This is due to the fact that there are areas that are inhabited predominantly by dense vegetations of oaks and a fauna that are able to destroy, make sick or kill ruthlessly a person who ventured to pass through these areas without protection.

In the Veladero there are some springs that have water at least ten months a year. During the rainy season, runoffs are created causing infiltration through fractures and faults. The streams flow with such force and volume runoffs can cause mishaps at the bottom of the hill in the bay of Acapulco such as floods, accumulation of silt, and even vehicle rollovers [2].

The government's decision to expropriate the Veladero hill and convert it into a protected area is invaluable to the bay of Acapulco and its inhabitants. By 1980 the population of the city had grown to 410,000 [3] who lived exclusively on the economic impact of tourism. The development of the national park is removing some of the causes that contributed to the pollution of the bay of Acapulco.

The ability to analyze and measure the features and the benefits that can substantially impact the bay of Acapulco are difficult to separate from the huge dependence on Acapulco's tourism which is $70 \%$ of its economy. Acapulco in the 1940 was a quiet little village, rich in tradition, with a strong cultural identity and stunning natural environment [4]. An old fishing village that grew quickly and spontaneously from the tourist explosion in early 50s have suffered since 1980 in a series of processes that have led to changes in Acapulco's population and lifestyle.

Like all Mexican tourist destinations Acapulco became a mirror territory attracting and seducing thousands of migrants from all over the state in search of a better lifestyle. Migrants with only elementary education found only rejection, marginalization, and discrimination. This led to their working as street vendor with meager incomes, which led to the founding of colonies in the amphitheater of the bay of Acapulco. These colonies were without basic services of water, sewer and garbage collection causing them to eventually become slums. These migrant developments have caused environmental changes that have caused negative affected to the bay of Acapulco, and discredited the tourist destination image. 
Acapulco has seen change to its economic structure at an accelerated rate going from a population mainly dedicated to the predominance of the primary sector and more specifically to tertiary tourism. With a population that was not prepared for the economic boom that occurred or for the results of the social tourism that became an exclusive creator of poverty. A population that should have been immune to these changes rather than being affected negatively was in large part because the government authority was not prepared to provide essential services for human development of the population.

With the economic improvement of only part of its inhabitants has been a process of abandonment to the colonies that have invaded the Veladero hill or more peripheral areas of the city. At the same time, this has given rise to a recruitment process behind the hills by lower income families and who sadly belong to marginalized groups and ethnicities from the same state. Among these new residents are mostly ethnic families who do not speak Spanish, and have another set of values and priorities, especially in regard to food, clothing and housing [5].

These groups of people existing in extreme poverty generate a series of needs that the government authority does not have the economic resources to provide. These colonies contribute to altering the landscape; they fill spaces that are high risk territories for life in areas like the hill canyons, deforesting the Veladero to build cardboard houses, sleeping on the ground, without safety and clean homes. During the rainy season these groups must be evicted and carried to safety.

This fact, coupled with poor purchasing power and marginalization suffered from Mexican social cores themselves, have led the tourist destination of Acapulco to a state of environmental degradation and ruin. This demonstrated through recurrent violence cases and increasing conflict and development economy activities like drugs, which are now the easy way to obtain money. The outcome of unexpected events of overcrowding forced the government to decree in 1980 [6] that the Veladero hill surrounding the bay of Acapulco as a Protected Natural Area (PNA), generating a whole social movement to drive out by choice or by police force the entire population that had penetrated the inhospitable areas of the Veladero hill.

\section{The beginning of the socio-environmental problems in Acapulco}

Rapid population growth led to serious problems for a city that was not well planned to accommodate the local people in addition to the floating population of visitors. This led to devastating consequences caused by the fact that 125,000 people lived in the hill top of the Veladero [7]. A major problem was the increased pollution due to the settlement of people who came to Acapulco in search of employment opportunities, but without the education and training necessary to access decent jobs, forcing them to seek refuge on the slopes of the Veladero leading to precarious conditions.

So, in the beginning of the year of 1980 an entire program was planned to relocate the 125,000 inhabitants of the amphitheater of the bay of Acapulco and 
bring to an end what would be found behind the Renaissance city from closing the Veladero and build a new population center.

"The governor himself has reported that this has been struggle from the beginning of his regime (1975) because it is necessary to prevent pollution of the waters of the bay. Now even the president of the republic has recognized this and from the social point of view the work that has started is great because we can provide improvement for those living in subhuman conditions and unrest in land tenure. Although we believe that there will be serious problems of different types that will arise, we insisted on better safe than sorry, as the major problem to be solved in Acapulco is irregular human settlements that generate pollution, but that can be avoided with these measures" [8].

The problem has been generated by the tolerance of the authority of allowing unsuitable land to be invaded by citizens to live on is a measure that is advertised as a remedy to pollution of the bay. Therefore, the Autonomous University of Guerrero proposed that a commission on area technical engineering, architecture, biology and medicine will perform a thorough and comprehensive study of the case to determine as accurately as possible, the causes of this phenomenon and seek their ultimate solution.

The relocation task was not an easy as process as villagers resisted civil and legal authorities according to many observers,[9] repeatedly hundreds of settlers from the Acapulco amphitheater performed frequent demonstrations outside the offices of the city hall of Acapulco, demanding that the city hall consider the organization of popular sectors that are above the line of 225 meters from sea level and that lack the most essential services; also asked that the government should expand their reporting of the work done for the relocation of those who would be evicted by fulfilling the promises made by the state governor about the relocation. To inform the settlers whom have the right of those affected by this necessary relocation and to be informed on the progress of work on the new Renaissance population center.

The local university "believes that the move will be done to relocate and move the 12,500 families living in the highlands of Acapulco to flat surfaces, is simply the execution of a relocation project and not a serious plan to solve the problem of pollution in the bay, because if it was a serious plan, the government would be planning to build sewage processing plants and similar measures" [10].

The rector of the local university said that "the proposed relocation is not in the opinion of the university, the ideal answer to solving the problem of serious pollution of the bay and noted that the university shares with the state government's opinion that this is the No. 1 issue of Acapulco, but definitely not the relocation of the 125,000 settlers living in the hills as a solution to fix the problem. The only thing that would make the government move to another site is contamination factors not properly planned for with the relocation of the settlers of the amphitheater of the bay.

Indeed, in a technical presentation of the problem, experts noted that human nuclei settled in the hills produce some contamination by lack of drainage and utilities, but that in the place where you plan to relocate them, the government 
would be draining wastes to the open sea where they would go anyway from the bay by the action of internal currents.

The federal and state government have thought that the relocation of 12,500 families living in the highlands of the Veladero hill of Acapulco was the only measure to curb pollution of the waters of the bay that ultimately poses a serious and imminent danger to destroy the tourism industry of the port. The mentality of the federal and state government is that it is only the settlers who generate pollution. There are many other factors that will need to be attacked simultaneously, as it is an integral operation [11].

The budget allocated by the state government for this plan included storm drainage and sewage, water supply, sewerage, total urban remodeling of other items that have been earmarked for the new human settlement, and payments for the renaissance and expropriated land. They have offered economic rewards to those who report and check sewage discharges to the bay.

Action which at the time sought to mitigate the depredation to the Veladero hill and keep it as an integrated ecosystem of the bay of Acapulco while preserving its flora and fauna as well as its aquifers as an adjunct to its reforestation caused by unchecked logging that carried out the inhabitants' rudimentary building of homes [12].

\section{Background of the natural protected areas in Mexico}

The International Union for Conservation of Nature (IUCN) [13] defines protected areas as: "An area of land or sea especially dedicated to the protection and maintenance of biodiversity and of natural and associated cultural resources, managed through legal or other effective means" [14].

This definition implies that protected areas are to preserve the biodiversity that exist, so it is protected from over-exploitation of natural resources. If not protected, over-exploitation and uncontrolled use of the resources could potentially cause the extinction of important species of both flora and fauna. This could result in serious social and environmental changes because these areas contain important resources such as water, food (animal and plant), and raw materials for the production of commercial items.

These areas also preserve the ecological balance, because if any human intervention, such as deforestation, may cause many species such as birds or mammals of different types to have the need to change habitats. These changes break the ecological balance, and could cause them to extend into areas where they have no natural predators.

The first country in the world to have a natural sanctuary was Sri Lanka when King Devanampiyatissa ordered in the third century the protection of wild life around the town of Mihintale. However, from remote antiquity there have been cultural practices that amounted to the establishment and maintenance of reserved areas for biota including fish, waterfowl or other animals. There may have been religious ones as "cursed forests" in some regions of Africa where humans would not go under threat of attacks by spirits. There were also sacred 
taboos prohibiting entry of humans to given locations. Such prohibitions exist in various parts of the world [15].

The early history of protected natural areas (PNA) in Mexico date back to pre-Hispanic times, The Maya, for example, included within their production systems strict protection of certain areas and rest periods for exploited areas. In the fifteenth century Netzahualcóyotl reforested areas near the Valley of Mexico and during the sixteenth century, the emperor Moctezuma II founded some zoos and botanical gardens [16].

\section{Legal framework for the expropriation of a natural protected area in Mexico}

The environmental issue is the preservation of the structural axis against political and social interests. This park represents a significant element of support for the sustainability of the bay of Acapulco. It is necessary to demand urgent action from the whole regulatory framework in order to respect its biosphere, "because what happens at the top of the park Veladero affects the health of the city beaches that maintain a high resilience to the ravages of the urban sprawl” [17].

From awareness of the situation of environmental degradation, of incalculable proportions for the entire planet arise various proposals to try to resolve or at least slow its deterioration from the eco-development of the early seventies, up to the sustainable development at the present, have become the goal of many regions of the world, but it must be recognized that in the simulation prevails considerable actions by both countries and international organizations, that occur despite international treaties recently agreed to.

Social equity and economic benefit to improve the quality of life were the grounds for declaring Veladero hill as a protected area, from the proper use of resources to maintaining the ecological balance [18]. To achieve this it is essential to reconsider the scheme of values and ethical principles that govern society and, consequently, to redefine the model or style of development and propose compromises between the government and society. Based on an environmental ethic to reassess nature and man himself, respect for each other is the principle of this new paradigm for the future life [19].

So, the decree declaring the Veladero a Protected Natural Area, is a federal executive authority, set for public use, national parks on land because of its location, topographic configuration, exceptional beauty, scientific value, educational or recreational warrant, or will contribute to improving the living conditions and welfare of the community or contribute to tourism development, as well as perform the necessary work of preparation and organization.

It is understood that within the problems of human settlements and urban development facing the state of Guerrero, occupies a site of significant importance on the control of pollution and environmental health of the population centers, as well as the need woodland setting. At the same time to help solve the problems identified and represented, for the people that live in these areas, pleasant spaces for recreation and relaxation that improves the quality of life in the community. 
The city with the highest natural beauty is the port of Acapulco in Guerrero state, which by its conditions of climate and variety of subtropical vegetation, meet the requirements that are considered favorable for the establishment of a national park, to improve not only the aesthetic, but also influence habitat improvement of human settlements of the place and contribute to their recreation settings.

Studies were conducted and technical work necessary for the possible location of a green roof or wooded area that allows and contributes to preventing and combating environmental pollution end at the same time promote recreation and leisure activities. The results concluded that due to the topographical configuration, slope and weather conditions, and the hill was the only area of Veladero feasible to fulfill the purpose intended [20].

The lands that constitute the Amphitheatre Acapulco bay, which are described above, however, by its vocation and skills are suitable for the establishment of a national park, have been engaged in diverse areas for residential uses [21]. This is detrimental to the preservation of flora, leading to gradual erosion and degradation.

Besides the natural beauty that possess the grounds referred to this arrangement, as part of the Veladero hill should highlight its historical significance as it was an important site when the insurgent troops, under the command of Don Jose Maria Morelos y Pavón national hero, won a significant victory for the sake of independence of Mexico, this reason coupled with the above, justifies the establishment of a national park in this place for their preservation for the benefit of the community, and as a fitting tribute to one of the framers of the country.

To help achieve the objectives of the national policy on human settlements and allow the solution of the problem that confronts the issues highlighted in the City and Port of Acapulco, a national park should declare the above defined geographical area in order that is integrate and part of the National Park System for recreation. For the main purpose of preserving the ecosystem and to prevent the disruption or degradation of the hill based on multidisciplinary approaches to regulation and control measures and to make the site available for recreational purposes, allowing entrance to visitors and tourists on special conditions, with educational, cultural and recreational uses.

Being empowered by the state to acquire by way of public law grounds comprising national parks or required to attend to the needs of general interest should preferably be met, as well as for the realization of public works intended to undertake service providing collective services that also in this case, to help improve a population center.

The National Park should be maintained in order to preserve the balance of the ecosystems of the bay of Acapulco, otherwise, this area could suffer serious consequences such as: water shortages, landslides, silting, spread of disease and impaired tourism activities. The function of the park is to largely support the environment and the economic life of Acapulco, so it is necessary to take appropriate measures for its development. 


\section{Reforms of the Mexican congress to the general law on ecological balance and environmental protection (ecology law)}

The recent reform adopted article 47 bis of the ecology law [22] states that currently the General Law of Ecological Equilibrium and Environmental Protection, article 47 bis, that compliance with the provisions of this act, in relation to the establishment of protected areas, there will be a division and subdivision to identify and delineate the portions of land within it.

The said Article 47 bis, protected areas have two types of areas, core areas and buffer zones. Within the buffer zones are allowed up to eight types of subzones. The purpose of the proposed amendment to article 47 bis, is premised reform the sub section concerning recovery of buffer zones contained in that article 47 bis, section II, subsection h), which are those areas in which the natural resources have been severely altered or modified, and which are subject to recovery and rehabilitation programs.

That article 47 bis, section II, subsection h) states that recovery in these subzones "should preferably be for rehabilitation, species native to the region, or in your case, species compatible with the functioning and structure of the original ecosystems."

That is, with the current wording of this article you can use IAS (invasive alien species) for recovery efforts in a protected natural area, when it is a question of recovering in some way the original environment of ecosystems in protected natural areas, where native species will prevail in the recuperation program.

Consistent with this idea, the proposed text for the recovery sub buffer zones in reforming the said in article 47 bis, seeks both to promote not only the use of native species, as well as prevent the introduction of invasive alien species, by forcing the use of species that are scientifically shown to be compatible with the operation and structure of the original ecosystems.

Unfortunately deforestation in Mexico is advancing at a rate of $10 \%$ annually this in relation to the total vegetation that covers the nation. So far 700,000 hectares have been deforested. According to calculations currently approximately $17.4 \%$ of vegetation covers the country. Deforestation is the total or partial loss of vegetation cover on a site.

\section{Recurring threats to the Veladero hill demerit the sustainability of the tourist destination of Acapulco}

During the last sixty years tourism has been distinguished by being more available to the mass public, and the model has been replicated throughout the world, which allows choosing a destination at a lower price, usually sun and sand and eventually a city, in a place crowded. This has resulted in a set of social, economic, cultural and ecological changes in places of tourist reception. 
Tourist destinations in the coasts and beaches of warmer latitudes are the most demanded, therefore the impact on them has been, in some places, devastating, and the preservation and care of the quality of water is important, all while still prioritizing intensive development models.

The irrational use of natural resources has caused severe damage to the natural balance. These attacks begin with the construction of new facilities and continue with the daily management and operation of the tourism industry.

Tourist facilities are large consumers of water and energy; similarly they generate large volumes of solid waste and air emissions, whit emissions from refrigeration, air conditioning, the firefighting equipment, foam insulation, spray drivers among others [23].

The Veladero hill is relevant to the healthy development of Acapulco as Mexico's iconic tourist destination because in 2012, the city received 9, 2 million tourists 95\% domestic and 5\% international [24] making it dependent on tourist flows. This creates a threat because that visiting population is not educated to respect the environment which generates cascading problems for the destination.

On the other hand, hundreds of migrants arrive at the destination each year in search of employment, generating housing needs, which in the absence of availability, resort to land invasions in the upper parts of the Veladero hill where the municipality is unable to provide water, sewer and garbage collection, so that in the rainy season from June to September every year, inevitably wastes are emptied into the bay.

Police of Acapulco are constantly dismantling huts and fences made with barbed wire in the ecological areas that are erected to demarcate areas or hectares for people that claim to buy off false leaders of political parties or people to sell to people in extreme poverty who seek to live. These impoverished people fall prey to the unscrupulous people who know that this land cannot be sold because of the protected area status. However, burst into the Veladero the illegal business to grab land fraudulently and sell to innocent persons.

Currently it is estimated that approximately 41 settlements have invaded the hill again given laxity of Veladero successive governments comprising of 8,349 families consisting of 41,745 inhabitants [25] causing deforestation, changes in land use, natural wildlife migration site, emerging slums, extreme poverty, domestic violence, crime and social exclusion, putting at risk the entire ecosystem environment integrated Acapulco bay.

\section{Proposal for conservation and management of the Veladero protected natural area}

The Environment and Natural Resources Secretariat (SEMARNAT) may apply from the year of 2013, self-employed, director of coordination or through service providers interested, a set of actions in accordance with the rules of operation of the programs forestry development with financial support in the categories of conservation and restoration, reforestation, soil restoration, prevention and combat of forest fires, forest health and environmental services designed to support the maintenance of forest areas that promote groundwater recharge, 
catch carbon and biodiversity protection, all these, under grant federal program coordination and ProArbol (Pro tree) [26].

These actions would have to start immediately to have a chance to meet the calls to the National Forestry Commission (CONAFOR). These initiatives would create action awareness of the population located in the boundaries of the protected natural area, as these groups would be invited to participate in rehabilitation programs in their early stages, with consequent economic benefit to marginalized groups who are willing to work.

SEMARNAT must by the Federal Attorney for Environmental Protection (PROFEPA) and federal prosecutors agencies, exercise the strict application of the law to those who have led invasions that practice for profit or political purposes, those who have deforested flagrantly irresponsible, who fraudulently sold grounds that were protected natural areas and acted in conflict with the provisions set forth in the decree of 2000, which were published in the official gazette and therefore have character federal law.

SEMARNAT must convene the parties involved from the public sectors and civil societies that are interested in administering, monitoring, and managing the Protected Natural Area in accordance with the guidelines established in the program of management. This group needs to perform in a participatory manner with agreements that include the corresponding points of the decree of 2000, the General Law of Ecological Equilibrium and Environmental Protection (ecology law) and the existing rules and regulations under the direction of SEMARNAT as well as the participation and collaboration of all three bodies of government, national, state and municipal agencies, related to the preservation of the ecosystems and environmental sustainability as an integrated product to the Acapulco tourist destination.

\section{Conclusion}

The purpose of the declaration of a Protected Natural Area (PNA) "Conserving biodiversity is representative of different ecosystems to ensure balance and continuity of ecological and evolutionary processes and whose features have not been substantially modified" [27] however in Mexico, the actions undertaken by different agencies responsible for it, show that only documents reveal that it has complied with laws, regulations and treaties and international commitments signed by the Mexican government, although in reality the facts and the results show that it has regressed.

Clearly, decision makers are not aware of the reason for a declaration of (PNA) and the importance of this is the preservation of human life itself, when nature has provided the resources (matter) that are transformed (energy) for man to continue life, and that without them being repaid in the short term, the chances of survival, not only of resources, but human beings also.

Although Acapulco has had since 1993 a regulation for the protection of the environment, it has been modified for the convenience of the incumbent leaders and their commitments to investors, tourism developers, resulting in the decrease of environmental conditions. 


\section{References}

[1] INEGI, Instituto Nacional de Estadística y Geografía. p. 16, México 2003.

[2] Vargas, F., Parques Nacionales de México y Reservas Equivalentes. Pasado, presente y futuro. Colección: Grandes Problemas Nacionales. Serie: Los Bosques de México. Instituto de Investigaciones Económicas. UNAM. México, D.F. pp. 105-106, 1984.

[3] INEGI., Municipios de Guerrero, p. 2, México www.municipios.com.mx /guerrero/mexico. 2012.

[4] Gómez, S. y Aldama, M., Modernidad y Turismo: repercusiones en el caso de Acapulco. Guadalajara, Jalisco: Pandora. p. 84, México, 2007.

[5] Diagnostico del parque Nacional El Veladero, Estado de Guerrero., Subsecretaria forestal y de fauna. Promotora Agropecuaria Universal, S.A de C.V. p. 42, 1993.

[6] Diario Oficial de la Federación- DOF, Órgano oficial de Divulgación del gobierno mexicano. pp. 6-9, 1980.

[7] Secretaria de gobernación del Estado de Guerrero., Censo de Población arriba de la línea isobárica. p. 12, México 1980.

[8] Figueroa, R., Informe de gobierno- Gobernador Constitucional Del Estado de Guerrero, pp. 29.21, México, 1975-1981.

[9] Martínez, A., Memoria de Acapulco. Acapulco, Guerrero, p. 45, México, 1994.

[10] Wences. R, Rector de la Universidad Autónoma de Guerrero, p. 5 México, 1980.

[11] Instituto Nacional de Ecología., Parque Nacional el Veladero. es.wikipedia.org./wiki/Parque_nacional_el_Veladero.

[12] Comisión Nacional para el Conocimiento y Uso de la Biodiversidad (CONABIO) www.conabio.gob.mx

[13] La Unión Internacional para la Conservación de la Naturaleza, UICN. www.iucn.org/es/ 1994.

[14] La Unión Internacional para la Conservación de la Naturaleza (UICN) p. 8, México, 1994.

[15] King Devanampiya Tissa of Anuradhapura, Sri Lanka www.buenastareas.com/materias/reservas.../0(15)

[16] en .wikipedia.org/wiki//Nezahualcoyot

[17] Sánchez. A., Instituto Mexicano de Estudios Políticos, A.C. Estudio Sociopolítico del Parque Nacional "El Veladero”. Sánchez. A; Investigación Camacho. C. Téllez A; Asistentes: García. E. Rosillo. J.P. Franco. C. pp. 133-135. México, 1993.

[18] Secretaria de Medio Ambiente y Recursos Naturales, (SEMARNAT) México. 2000 www.semarnat.gob.mx/

[19] Llata, D, Ecología y Medio Ambiente, editorial progreso. S.A.de C.V. p. 63, México, 2003.

[20] Fundamentos para el de decreto expropiatorio concretizado, por El presidente de la república mexicana. pp. 1-24, México, 1980. 
[21] López, J., Presidente Constitucional de los Estados Unidos Mexicanos. Secretaría de Asentamientos Humanos y Obras Públicas. "Decreto por el que se declara Parque Nacional, con el nombre de El Veladero, el área que corresponde a los terrenos que constituyen el anfiteatro de la bahía de Acapulco”. Diario Oficial de la Federación, 17 de julio 1980, pp. 1-24, México, 1980.

[22] Ley General de Equilibrio Ecológico y Protección al Ambiente. (LGEEPA) Reformas del Congreso mexicano del a la Ley General Equilibrio Ecológico y Protección al Ambiente, 3 de abril del 2013.

[23] Avilez, H. T. Rivas and Ma. E. Chavarría., Cambio climático y Turismo, Ponencia presentada en el marco del $1 \mathrm{~V}$ Congreso Internacional De la Academia Mexicana de Investigación Turística A.C. (AMIT) pp. 1-14, México, 2010.

[24] Compendio de Estadísticas turísticas. pp. 1-146, Acapulco, Gro México, 2012.

[25] Comisión Nacional de Áreas Naturales Protegidas (CONANP). México 2012 www.conanp.gob.mx/

[26] Carrillo, G., Ingeniero Geólogo, Facultad de Ingeniería, Universidad Nacional Autónoma de México (UNAM), México, 2012.

[27] Rivas, G., Propuesta de programa de conservación y manejo del Area natural protegida el cerro el Veladero, por la Presidente del Colegio de ecólogos del Estado de Guerrero. A.C. pp. 1-21, Acapulco, México, 2012. 